\title{
THE EFFECTS OF LOW DOSE HORMONE THERAPY ON SERUM LIPID PROFILE, GLISEMIC CONTROL, THYROID HORMONES AND ANDROGEN LEVELS IN POSTMENOPAUSAL WOMEN
}

\author{
A. Yasemin Karageyim KARSIDAG, Nevriye ALKAN, Esra Esim BUYUKBAYRAK, Bulent KARS, \\ Meltem PIRIMOGLU, Orhan UNAL, M. Cem TURAN \\ ${ }^{1}$ Department of Obstetrics and Gynecology, Dr. Lutfi Kirdar Education and Research Hospital, Kartal, Istanbul, Turkey
}

\section{SUMMARY}

Objective: To compare the effects of norethisterone acetate (NETA) and drospirenone on thyroid hormones, glisemic control, serum lipid profile and androgen levels.

Material and methods: 50 postmenopausal women with intact ovaries \& uterus who have vasomotor complaints but otherwise healthy were prospectively enrolled into the study and 41 of them completed the study. Patients were randomly divided into two groups and prescribed $1 \mathrm{mg} E_{2} / 0.5 \mathrm{mg}$ NETA $(n=21)$ or $1 \mathrm{mg} 17 \beta E_{2} / 2 \mathrm{mg}$ drospirenon $(n=20)$ for 3 months. After the treatment thyroid hormones, glisemic control, lipid profile and androgen levels were compared both within the groups and between the groups. For the statistical analysis besides descriptive statistical methods paired and unpaired t test, Mann-Whitney U test and chi square test were used. Statistical significance level was accepted as $p \leq 0.05$.

Results: There was no difference regarding body mass index (BMI), endometrial thickness and thyroid hormones both within the groups and between the groups after the treatment. Total cholesterol $(p=0.03)$, insulin $(p=0.009)$, Homeostasis model assessment (HOMA) $(p=0.01)$ and fibrinogen $(p=0.01)$ levels were decreased in NETA group after three months. In drospirenon group there was decrease in LDL cholesterol level $(p=0.02)$, increase in trigliseride level $(p=0.04)$. There was decrement in total testosterone level in both NETA $(p=0.0001)$ and drospirenon (0.001) groups.

Conclusion: NETA have beneficial effects on both lipid and carbohydrate metabolism in postmenopausal women. Drospirenon decreases LDL cholesterol while increasing trigliseride level and has no effect on carbohydrate metabolism. Under the light of these data it is wise to suggest NETA containing low dose hormone therapy preparations in postmenopausal women with diabetes risk for controlling vasomotor complaints.

Key words: drospirenone, glucose, lipid, menopause, norethisterone acetate, thyroid

Journal of Turkish Society of Obstetrics and Gynecology, (J Turk Soc Obstet Gynecol), 2011; Vol: 8 Issue: 2 Pages: 125 - 33

Address for Correspondence: A. Yasemin Karageyim Karsidag. Bayar cad. Okur sok. 5/7 Kozyatağı, Kadıköy, İstanbul, Turkey Phone: +90 (216) 4647236

e-mail: ykarageyim@yahoo.com

Received: 30 March 2010, revised: 16 December 2010, accepted: 09 March 2011, online publication: 14 Manch 2011 


\section{ÖZET}

\section{DÜŞÜK DOZ HORMON TEDAVISINIIN POSTMENOPOZAL KADINLARDA LIPIID PROFILİ, GLISSEMIIK KONTROL, TIROID HORMONLARI VE ANDROJENLER ÜZERINE ETKILLERİ}

Amaç: Noretisteron asetat (NETA) ve drospirenonun tiroid hormonlarl, glisemik kontrol, serum lipid profili ve androjen seviyeleri üzerindeki etkilerinin karşılaştırılması.

Gereç ve yöntemler: Çalışmaya uterus ve overleri intakt, vazomotor şikayetleri olan sağllkl 50 postmenopozal kadın prospektif olarak dahil edildi, 41 kadın çalışmayı tamamladı. Randomize olarak iki gruba ayrılan olgulara 3 ay boyunca $1 \mathrm{mg} \mathrm{E} E_{2} / 0.5 \mathrm{mg} \operatorname{NETA}(n=21)$ ve $1 \mathrm{mg} 17 \beta E_{2} / 2 \mathrm{mg}$ drospirenon (n=20) verildi. Gruplar tedavi sonrast tiroid hormonlarl, glisemik kontrol, androjen ve kan lipid düzeyleri değişimleri açısından hem grup içi hem de gruplar arası değerlendirildi. Verilerin değerlendirilmesinde tanımlayıcı istatistiksel metotların yanı sıra, bağımsız t testi, eşleştirilmiş t testi, Mann-Whitney U testi ve ki-kare testi kullanıldı. Sonuçlar, anlamlılık $p \leq 0.05$ düzeyinde değerlendirildi.

Bulgular: Vücut kitle indeksi (VKI), endometriyal kalınlık ve tiroid hormonlarında tedavi sonrası her iki grupta grup içi ve gruplar arası fark saptanmadı. 3 aylık tedavi sonunda NETA grubunda total kolesterol $(p=0.03)$, insülin $(p=0.009)$, Homeostasis model assessment $(H O M A)(p=0.01)$ ve fibrinojende $(p=0.01)$ düşüş gözlendi. Drospirenon grubunda ise $L D L$ kolesterolde düşüş $(p=0.02)$, trigliseritte ise artış saptandı $(p=0.04)$. Total testosteronda hem NETA ( $p=0.0001)$ hem de drospirenon grubunda $(p=0.001)$ tedavi sonrası düşme oldu.

Sonuç: NETA postmenopozdaki kadınlarda hem lipid hem de karbonhidrat metabolizmasinı olumlu etkilemektedir. Drospirenon LDL kolesterolü düşürürken trigiseritleri arttırmaktadır, karbonhidrat metabolizmasına ise etkisizdir. Diyabet riski olan olgularda vazomotor semptomları gidermek için düşük dozlu NETA içeren hormon tedavisi (HT) tercih edilebilir.

Anahtar kelimeler: drospirenon, kan şekeri, lipit, menopoz, norethisteron asetat, tiroit

Türk Jinekoloji ve Obstetrik Derneği Dergisi, (J Turk Soc Obstet Gynecol), 2011; Cilt: 8 Sayl: 2 Sayfa: 125- 33

\section{INTRODUCTION}

Nowadays, reported results regarding the usage of hormone treatment (HT) in menopause are contradictory. According to the results of a randomized study, it was stated that HT isn't useful and may even be harmful in preventing the cardiovascular diseases during post menopause and that breast cancer increased in women ${ }^{(1)}$. Due to these contradictions, HT is recommended to be used in minimal acting doses and for short term in the cases with dominant vasomotor symptoms. Increase of low density lipoprotein (LDL), cholesterol and triglyceride, hyperinsulinemia and hyperandrogenemia are the risk factors for coronary heart diseases ${ }^{(4)}$. Negative effects of the medicines on lipid and carbohydrate metabolism and endogen androgens should be taken into consideration when choosing HT. Positive changes determined in serum lipids during treatment with high dose HT were also determined during treatment with low dose $\mathrm{HT}^{(5)}$.
Besides, continuous combined estrogen-progesterone preparations increase the thyroid binding globulin (TBG) level but don't affect the thyroid stimulating hormone (TSH) and free thyroxin (fT4) level(7).

Norethysterone acetate (NETA) is a C-19 derivative and a strong progestational agent causing significant atrophy in endometrium compared to other progesterone compounds ${ }^{(2)}$. Nowadays, low dose HT-1 mg E2/ 0.5 mg NETA combination- is preferred because it both decreases vasomotor symptoms and vaginal bleeding incidence is very low $(2,3)$.

Furthermore, it has been reported that HT in postmenopausal period is more appropriate because of the positive effects of estrogen and NETA combination on insulin sensitivity ${ }^{(6)}$. Low dose- $1 \mathrm{mg}$ $\mathrm{E}_{2} / 0.5 \mathrm{mg}$ NETA- combination significantly decreases the fibrinogen level compared to the control( ${ }^{(8)}$ and doesn't change the serum androgen levels ${ }^{(9)}$.

Drospirenone with antiandrogenic and antimineralocorticoid activity is a new gestagen closest 
to natural progesterone and doesn't affect the beneficial effects of estrogen negatively(10). Drospirenone positively effects lipid metabolism by decreasing LDL cholesterol $^{(10)}$. It doesn't increase the risk in terms of cardiovascular diseases because it doesn't change the fasting blood glucose, insulin, fibrinogen and C-reactive protein levels in short-term treatment ${ }^{(11)}$.

There are publications in literature comparing the effects of NETA and drospirenone on a single system separately. In this study, it was aimed to compare the effects of short term usage of low dose HT preparations containing NETA and drospirenone on both serum androgens, thyroid hormones and, lipid and carbohydrate metabolisms.

\section{MATERIAL AND METHODS}

50 cases who has gone through menopause naturally and been in menopause for at least 1 year and attended to our hospital's menopause policlinic with vasomotor symptoms between the dates 01.03 .05 - 01.07 .06 were enrolled in our study, 41 cases completed the study. Patients with a previous or present cerebrovascular and cardiovascular disease, gallbladder disease, uncontrolled DM, abnormal liver function test results, thromboembolic disease, chronic kidney or liver disease, previous hormone replacement treatment history, use of continuous medicine history, abnormal pap smear result and known or suspicious estrogen-dependant tumor were excluded from the study. Consent form was signed by the subjects and principles of human subjects research determined in the Declaration of Helsinki were observed.

Age, menopause age, menopause duration, smoking habit, drug usage, sports and exercise history of all the patients were collected; physical inspection, gynecological inspection and height-weight measurement were performed and follow-up was started; inspections and measurements were repeated 3 months later. Body mass index (BMI) was obtained by dividing the weights in kilograms by square of the heights in centimeters.

Cases enrolled in the study were divided in 2 groups randomly using a sealed-envelope method: 1mg E2 $0.5 \mathrm{mg}$ NETA/ day (Activelle, Novo Nordisk, Turkey) was given to the cases in Group I ( $\mathrm{n}=21)$; $1 \mathrm{mg} 17 ß \mathrm{E}_{2}-$ $2 \mathrm{mg}$ Drospirenone (Angeliq, Bayer, Turkey) was given to the cases in Group II. The cases were called for control 3 weeks later.

Blood sample was taken from each subject for serum biochemistry and hormonal analyses between 08.30 and 09.30 following an overnight fasting of 8 hours. Fasting blood glucose (FBG), insulin, total cholesterol, LDL, very low density lipoprotein (VLDL) and high density lipoprotein (HDL), triglyceride, TSH, free triiyodothyronine (fT3), fT4, total testosterone, dehydroepiandrosterone sulphate (DHEAS), fibrinogen, activated partial thromboplastin time (APTT) values of the cases were determined at the beginning and 3 months later. In order to determine the insulin sensitivity, Homeostasis Model Assessment (HOMA) formula was used. HOMA formula is a cheap and easily applicable method that shows strong correlation with hyperinsulinemic euglycemic glucose clamp technique ${ }^{(12)}$. Mathematical formula is: [fasting blood glucose $/ \mathrm{mmol} / \mathrm{ml}$ ) $\mathrm{x}$ fasting insulin $(\mu \mathrm{mol} / 1)$ ] / 22.5. HOMA was calculated according to the formula both at the beginning and at the end of the treatment. Endometrial thicknesses were measured by the same physician both before and after the treatment by taking two endometrial leaves with transvaginal ultrasonography.

Power analysis was performed by using MS-DOS data system (G Power Version 2.0 University of Bonn, Bonn, Germany). Minimum 40 patients were calculated for the total of two groups with the power of 0.50 keeping the effect size at 0.65 and $\alpha$ error at 0.05 . Statistical analyses were performed with Graph Pad Prisma V.3 package software. In evaluation of the data, apart from the identifying statistical methods (mean, standard deviation) independent $t$ test was used in comparison of the pair groups, matched t test was used in determination of the changes before and after the treatment, chi-square test was used in comparison of the qualitative data. Rate of change was calculated by subtracting the post treatment values from the pre treatment values, values were evaluated with Mann-Whitney-U test by taking their distributions into consideration. Results were evaluated at the significance level of $\mathrm{p} \leq 0.05$.

\section{RESULTS}

The study was started with 50 cases and 41 of them completed the study. 4 cases from Group I and 5 cases from Group II were withdrawn from the study because 
they stopped taking the medicine themselves and didn't attend the control.

No statistical difference was determined among 2 groups in terms of age, exercise habit and BMI (Table I). Ages of the subjects were between 46 and 52 (mean, group I: $47.86 \pm 3.21$, group II: $46.4 \pm 3.42$ ) and menopause ages were between 1 and 3 years. Smoking habit was significantly higher in group II ( $\mathrm{p}=0.01)$.

There wasn't any difference in endometrial thickness measurements between two groups before and after the treatment (Table I). No difference in endometrial thickness was determined within the group in both groups after the 3 months treatment. BMI didn't differ within the group and among the groups at the end of the treatment (Table I).

There was no difference in lipid parameters between the groups before the treatment (Table II); at the end of the 3 months of treatment, triglyceride $(p=0.05)$ and VLDL cholesterol $(p=0.008)$ were higher in group II. At the end of the treatment, total cholesterol in group $\mathrm{I}(\mathrm{p}=0.03)$ and LDL cholesterol in group II $(\mathrm{p}=0.02)$ decreased significantly within the groups; triglyceride increased in group II ( $\mathrm{p}=0.04)$ (Table II).

Before the treatment, FBG $(p=0.008)$, insulin $(p=0.01)$ and HOMA ( $\mathrm{p}=0.005)$ values were higher in group $\mathrm{I}$. This difference persisted in insulin $(\mathrm{p}=0.01)$ and HOMA

Table I: Comparisons of body mass index and endometrial thickness within and among the groups before-after treatment.

\begin{tabular}{|c|c|c|c|c|c|c|}
\hline & & \multirow[t]{2}{*}{$\begin{array}{l}\text { Group I } \\
(\mathrm{n}: 21)\end{array}$} & \multirow[t]{2}{*}{$\begin{array}{l}\text { Group II } \\
(\mathbf{n}: 20)\end{array}$} & \multirow[t]{2}{*}{$\mathbf{p}^{\varphi \varphi}$} & \multicolumn{2}{|c|}{$\begin{array}{l}\% 95 \text { Confidence } \\
\text { Interval }\end{array}$} \\
\hline & & & & & Low & High \\
\hline Body Mass & Baseline & $28.73 \pm 4.03 *$ & $26.23 \pm 3.16$ & 0.06 & 0.2 & 14 \\
\hline İndex & 3 months later & $28.79 \pm 3.54$ & $27.47 \pm 3.3$ & 0.26 & -0.5 & 19 \\
\hline & $\mathrm{p}^{\varphi}$ & 0.20 & 0.31 & & & \\
\hline Endometrial & Baseline & $2.73 \pm 0.79$ & $2.83 \pm 1.26$ & 0.77 & -1.2 & 1.3 \\
\hline Thickness & 3 months later & $3.32 \pm 2.01$ & $3.25 \pm 1.69$ & 0.91 & -0.79 & 0.59 \\
\hline & $\mathrm{p}^{\varphi}$ & 0.14 & 0.38 & & & \\
\hline
\end{tabular}

Group I: $1 \mathrm{mg} \mathrm{E2/0.5} \mathrm{mg} \mathrm{NETA} \mathrm{areas}$

Group II: $1 \mathrm{mg}$ 17ß estradiol/ drospirenone areas

*: Mean \pm Standard deviation

$p^{\varphi}:$ Matched t test

$p^{\varphi \varphi}:$ Independent t testi

Table II: Comparisons of the lipid values in blood within and among the groups before-after treatment.

\begin{tabular}{|c|c|c|c|c|c|c|}
\hline & & \multirow[t]{2}{*}{$\begin{array}{l}\text { Group I } \\
(\mathrm{n}: 21)\end{array}$} & \multirow[t]{2}{*}{$\begin{array}{l}\text { Group II } \\
(\mathbf{n}: 20)\end{array}$} & \multirow[t]{2}{*}{$\mathbf{p}^{\varphi \varphi}$} & \multicolumn{2}{|c|}{$\begin{array}{l}\% 95 \text { Confidence } \\
\text { Interval }\end{array}$} \\
\hline & & & & & Low & High \\
\hline \multirow[t]{3}{*}{ Total cholesterol (mg/dl) } & Baseline & $210.24 \pm 49.68 *$ & $218.4 \pm 33.55$ & 0.58 & -38 & 21 \\
\hline & 3 months later & $194.71 \pm 44.05$ & $202.6 \pm 26.97$ & 0.54 & -33.96 & 18.19 \\
\hline & $\mathrm{p}^{\varphi}$ & 0.03 & 0.06 & & & \\
\hline \multirow[t]{3}{*}{ Triglyceride (mg/dl) } & Baseline & $133 \pm 82.51$ & $107.87 \pm 42.45$ & 0.28 & -22 & 72 \\
\hline & 3 months later & $103.86 \pm 39.74$ & $140.07 \pm 67.33$ & 0.05 & -72.53 & -1 \\
\hline & $\mathrm{p}^{\varphi}$ & 0.10 & 0.04 & & & \\
\hline \multirow[t]{3}{*}{ HDL (mg/dl) } & Baseline & $58.62 \pm 12.54$ & $63.4 \pm 12.36$ & 0.26 & -13 & 3.7 \\
\hline & 3 months later & $57.33 \pm 14.41$ & $61.47 \pm 15.36$ & 0.41 & -14.3 & 6.04 \\
\hline & $\mathrm{p}^{\varphi}$ & 0.73 & 0.41 & & & \\
\hline \multirow[t]{3}{*}{ VLDL (mg/dl) } & Baseline & $26.51 \pm 16.51$ & $53.37 \pm 67.55$ & 0.08 & -57 & 4.1 \\
\hline & 3 months later & $20.57 \pm 7.68$ & $44.67 \pm 38.68$ & 0.008 & -41.6 & -6.56 \\
\hline & $\mathrm{p}^{\varphi}$ & 0.09 & 0.53 & & & \\
\hline \multirow[t]{3}{*}{ LDL (mg/dl) } & Baseline & $117.98 \pm 39.56$ & $133.21 \pm 28.89$ & 0.21 & -39 & 9.2 \\
\hline & 3 months later & $114.93 \pm 32.3$ & $114 \pm 27.18$ & 0.92 & -19.8 & 21.7 \\
\hline & $\mathrm{p}^{\varphi}$ & 0.71 & 0.02 & & & \\
\hline
\end{tabular}

Group I: $1 \mathrm{mg}$ E2/ $0.5 \mathrm{mg}$ NETA areas

Group II: 1 mg 17ß estradiol/ drospirenone areas

*: Mean \pm Standard deviation

$p^{\varphi}:$ Matched t test

$p^{\varphi \varphi}:$ Independent t testi 
$(\mathrm{p}=0.01)$ values after the treatment (Table III). In group I, insulin $(\mathrm{p}=0.009)$ and HOMA $(\mathrm{p}=0.01)$ values decreased significantly within the group with the treatment.

No difference was determined in thyroid hormone levels either within or among the groups after the treatment (Table III).

While DHEAS didn't change, total testosterone decreased significantly in both group I $(\mathrm{p}=0.0001)$ and group II $(\mathrm{p}=0.001)$ after the treatment, but there was

Table III: Comparisons of glycemic parameters and thyroid hormones within and among the groups before-after the treatment.

\begin{tabular}{|c|c|c|c|c|c|c|}
\hline & & \multirow[t]{2}{*}{$\begin{array}{l}\text { Group I } \\
(\mathrm{n}: 21)\end{array}$} & \multirow[t]{2}{*}{$\begin{array}{l}\text { Group II } \\
(\mathrm{n}: 20)\end{array}$} & \multirow[t]{2}{*}{$\mathbf{p}^{\varphi \varphi}$} & \multicolumn{2}{|c|}{$\begin{array}{l}\% 95 \text { Confidence } \\
\text { Interval }\end{array}$} \\
\hline & & & & & Low & High \\
\hline \multirow{3}{*}{$\begin{array}{l}\text { Fasting blood glucose } \\
(\mathrm{mg} / \mathrm{dl})\end{array}$} & Baseline & $104.29 \pm 16.55^{*}$ & $90.67 \pm 9.98$ & 0.008 & 3.85 & 2.3 \\
\hline & 3 months later & $100 \pm 14.82$ & $92.53 \pm 7.49$ & 0.08 & -1.0 & 15.94 \\
\hline & $\mathrm{p}^{\varphi}$ & 0.19 & 0.31 & & & \\
\hline \multirow[t]{3}{*}{ Insulin $(\mu \mathrm{U} / \mathrm{ml})$} & Baseline & $12.95 \pm 4.25$ & $9.28 \pm 3.89$ & 0.01 & 1.84 & 6.4 \\
\hline & 3 months later & $10.96 \pm 3.85$ & $8.1 \pm 2.54$ & 0.01 & 1.53 & 5.17 \\
\hline & $\mathrm{p}^{\varphi}$ & 0.009 & 0.24 & & & \\
\hline \multirow[t]{3}{*}{ HOMA } & Baseline & $3.36 \pm 1.4$ & $2.1 \pm 0.94$ & 0.005 & 1.1 & 6.4 \\
\hline & 3 months later & $2.73 \pm 1.14$ & $1.85 \pm 0.63$ & 0.01 & 1 & 3.3 \\
\hline & $\mathrm{p}^{\varphi}$ & 0.01 & 0.32 & & & \\
\hline \multirow[t]{3}{*}{ TSH $(\mu \mathrm{IU} / \mathrm{ml})$} & Baseline & $1.65 \pm 1.05$ & $1.47 \pm 1.05$ & 0.61 & -0.5 & 0.8 \\
\hline & 3 months later & $1.44 \pm 1.26$ & $1.25 \pm 0.59$ & 0.60 & -0.52 & 0.89 \\
\hline & $\mathrm{p}^{\varphi}$ & 0.12 & 0.37 & & & \\
\hline \multirow[t]{3}{*}{ Ft3 (pmol/l) } & Baseline & $5.24 \pm 0.6$ & $5.4 \pm 0.66$ & 0.45 & -0.96 & 0.19 \\
\hline & 3 months later & $5.17 \pm 0.82$ & $5.56 \pm 0.88$ & 0.18 & -0.95 & 0.19 \\
\hline & $\mathrm{p}^{\varphi}$ & 0.73 & 0.53 & & & \\
\hline \multirow[t]{3}{*}{ Ft4 (pmol/1) } & Baseline & $15.6 \pm 1.37$ & $16.82 \pm 1.36$ & 0.01 & -1.9 & -1.1 \\
\hline & 3 months later & $16.1 \pm 1.52$ & $16.41 \pm 1.42$ & 0.53 & -1.3 & 0.9 \\
\hline & $\mathrm{p}^{\varphi}$ & 0.20 & 0.38 & & & \\
\hline
\end{tabular}

Group I: $1 \mathrm{mg}$ E2/ $0.5 \mathrm{mg}$ NETA areas

Group II: $1 \mathrm{mg}$ 17ß estradiol/ drospirenone areas

*: Mean \pm Standard deviation

$p^{\varphi}:$ Matched t test

$p^{\varphi \varphi}:$ Independent t testi

Table IV: Comparisons androgens and coagulation values within and among groups before-after the treatment.

\begin{tabular}{|c|c|c|c|c|c|c|}
\hline & & \multirow[t]{2}{*}{$\begin{array}{l}\text { Group I } \\
(\mathrm{n}: 21)\end{array}$} & \multirow[t]{2}{*}{$\begin{array}{l}\text { Group II } \\
(\mathrm{n}: 20)\end{array}$} & \multirow[t]{2}{*}{$\mathbf{p}^{\varphi \varphi}$} & \multicolumn{2}{|c|}{$\begin{array}{l}\% 95 \text { Confidence } \\
\text { Interval }\end{array}$} \\
\hline & & & & & Low & High \\
\hline \multirow[t]{3}{*}{ Total testosterone $(\mathrm{pg} / \mathrm{dl})$} & Baseline & $0.9 \pm 0.59 *$ & $1.33 \pm 0.86$ & 0.08 & -0.48 & 0.24 \\
\hline & 3 months later & $0.53 \pm 0.4$ & $0.65 \pm 0.67$ & 0.50 & 0.65 & 0.67 \\
\hline & $\mathrm{p}^{\varphi}$ & 0.0001 & 0.001 & & & \\
\hline \multirow[t]{3}{*}{ DHEAS** (mg/dl) } & Baseline & $119.09 \pm 35.23$ & $100.66 \pm 37.99$ & 0.14 & -13 & 36 \\
\hline & 3 months later & $107.13 \pm 37.7$ & $95.19 \pm 34.5$ & 0.33 & -13 & 37.1 \\
\hline & $\mathrm{p}^{\varphi}$ & 0.10 & 0.14 & & & \\
\hline \multirow[t]{3}{*}{ Fibrinogen (mg/dl) } & Baseline & $360.12 \pm 100.73$ & $331.43 \pm 74.37$ & 0.35 & -33 & 91 \\
\hline & 3 months later & $327.91 \pm 69.84$ & $323.41 \pm 66.64$ & 0.84 & -42 & 51.59 \\
\hline & $\mathrm{p}^{\varphi}$ & 0.01 & 0.43 & & & \\
\hline \multirow[t]{3}{*}{ APTT*** (seconds) } & Baseline & $30.56 \pm 2.79$ & $28.07 \pm 3.08$ & 0.01 & 1.48 & 4.48 \\
\hline & 3 months later & $29.71 \pm 2.7$ & $29.06 \pm 2.83$ & 0.48 & -1.23 & -2.54 \\
\hline & $\mathrm{p}^{\varphi}$ & 0.14 & 0.43 & & & \\
\hline
\end{tabular}

Group I: $1 \mathrm{mg} E_{2} / 0.5 \mathrm{mg}$ NETA areas

Group II: 1 mg 17ß estradiol/ drospirenone areas

*: Mean \pm Standard deviation

$p^{\varphi}$ : Matched t test

$p^{\varphi \varphi}:$ Independent t testi 
no difference between the groups (Table IV).

APTT didn't change with the treatment whereas fibrinogen decreased significantly within the group I $(\mathrm{p}=0.01)$ (Table IV).

When percentage change differences were calculated before and after the treatment, increases in triglyceride and APTT in group II were significant compared to the decrease in group $\mathrm{I}(\mathrm{p}=0.05, \mathrm{p}=0.04$ respectively) (Table V).

Vaginal spotting occurred in 2 cases in group I ( 9.5 $\%$ ) and in 3 cases in group II (15\%). No adverse effects were seen in the cases except for mastalgia development in 2 cases in group I (9.5\%). Besides, none of these women stopped taking the medicine at the end of three months because of the adverse effects.

Table V: Comparison of the findings by the change difference beforeafter treatment.

\begin{tabular}{|c|c|c|c|}
\hline $\begin{array}{l}100 \text { \% Değișim } \\
\text { Difference }\end{array}$ & $\begin{array}{l}\text { Group I } \\
(\mathrm{n}: 21)\end{array}$ & $\begin{array}{l}\text { Group II } \\
(\mathrm{n}: 20)\end{array}$ & $\mathbf{p}^{\varphi}$ \\
\hline Endometrial thickness & $-21.3 \pm 58.47^{*}$ & $-26.12 \pm 76.64$ & $\mathrm{NS} * *$ \\
\hline Body Mass Index & $0.16 \pm 7.06$ & $4.31 \pm 6.98$ & NS \\
\hline FBG & $-5.4 \pm 15.67$ & $2.01 \pm 7.6$ & NS \\
\hline Insulin & $-24.9 \pm 39.93$ & $-18.11 \pm 49.93$ & NS \\
\hline HOMA & $-32.86 \pm 50.36$ & $-17.05 \pm 53.83$ & NS \\
\hline Total cholesterol & $-8.98 \pm 16.66$ & $-8.52 \pm 15.07$ & NS \\
\hline Triglyceride & $-32.61 \pm 73.97$ & $13.13 \pm 32.39$ & 0.05 \\
\hline HDL & $-8.55 \pm 42.31$ & $-5.01 \pm 13.92$ & NS \\
\hline VLDL & $-32.51 \pm 73.45$ & $-15.03 \pm 100.62$ & NS \\
\hline LDL & $-6.92 \pm 34.66$ & $-21.77 \pm 34.99$ & NS \\
\hline TSH & $-50.15 \pm 97.18$ & $-44.97 \pm 108.04$ & NS \\
\hline $\mathrm{fT}_{3}$ & $-3.83 \pm 19.43$ & $1.02 \pm 16.36$ & NS \\
\hline $\mathrm{fT}_{4}$ & $2.32 \pm 11.8$ & $-3.14 \pm 11.83$ & NS \\
\hline Total testosterone & $-106.83 \pm 117.78$ & $-253.49 \pm 385.4$ & NS \\
\hline DHEAS & $-26.28 \pm 88.78$ & $-5.8 \pm 15.12$ & NS \\
\hline Fibrinogen & $-9.2 \pm 14.88$ & $-2.87 \pm 11.49$ & NS \\
\hline APTT & $3.23 \pm 9.12$ & $2.86 \pm 11.92$ & 0.04 \\
\hline \multicolumn{4}{|c|}{ Group I: $1 \mathrm{mg} E_{2} / 0.5 \mathrm{mg}$ NETA areas } \\
\hline \multicolumn{4}{|c|}{ Group II: $1 \mathrm{mg} 17 \beta$ estradiol/drospirenone areas } \\
\hline \multicolumn{4}{|c|}{$*:$ Mean \pm Standard deviation } \\
\hline \multicolumn{4}{|c|}{$* * N S:$ Not Significant } \\
\hline$p^{\varphi \varphi}:$ Mann-Whitney- $U t$ & & & \\
\hline
\end{tabular}

\section{DISCUSSION}

In this prospective study, effects of low dose HT regimen containing NETA and drospirenone on carbohydrate and lipid metabolisms and on thyroid and androgen hormone levels were compared. While NETA combination significantly decreased fasting insulin, HOMA, total cholesterol, total testosterone and fibrinogen levels, drospirenone combination significantly decreased LDL cholesterol and total testosterone levels. Drospirenone also significantly increased triglycerides. When two medicines were compared, triglyceride and APTT increasing of drospirenone was found more significant than that of NETA.

It has been reported that NETA's effect on lipid metabolism was decrease in total and LDL cholesterol; slight decrease in HDL cholesterol and none on triglyceride $(13,14)$. Consistent with the literature, significant decrease in total cholesterol and slight decrease in HDL, LDL, VLDL and triglyceride with NETA were also determined in this study. It has been suggested that drospirenone decreases the total cholesterol, LDL, VLDL $(15,16)$; increases ${ }^{(16)}$ or doesn't affect $(15,17)$ HDL due to its antiandrogenic effects. In this study it was determined that drospirenone decreased the total cholesterol slightly and LDL significantly, the results were consistent with the literature. There are publications stating that drospirenone doesn't affect ${ }^{(15)}$, slightly increases ${ }^{(16)}$ and increases the triglyceride at high doses ${ }^{(18-20)}$. In this research significant increase in triglyceride level was determined in drospirenone group. When two medicines were compared after the treatment, triglyceride increase in drospirenone group was found to be more significant than the decrease in NETA group.

Effects of HT containing NETA on FBG and insulin sensitivity are controversial in the literature; there are publications stating that it has no effect or causes deterioration $^{(21,22)}$. Dansuk et al have reported that 2 mg $E_{2}+1$ mg NETA changes the insulin sensitivity in postmenopausal women after a 3 months treatment ${ }^{(6)}$. In this study, fasting blood glucose decreased slightly in NETA group and decreases in insulin and HOMA value were found to be statistically significant. It has been suggested that insulin increases the endothelial cell growth and regulates the LDL receptor activity, so decrease in fasting insulin level is a factor protecting from cardiovascular diseases ${ }^{(23)}$. While it has been notified that drospirenone's effect is increase in blood glucose and glucose tolerance ${ }^{(18,19)}$, there are also opinions that it is ineffective on carbohydrate metabolism $^{(11,23)}$. Consistent with the literature; FBG increased insulin and HOMA values decreased slightly but without significance. Additionally, when two groups were compared in this study, decrease of insulin and 
HOMA value after treatment was more significant in NETA group than drospirenone group.

Hyperandrogenism is one of the risk factors for cardiovascular diseases ${ }^{(4)}$. There are publications stating NETA is ineffective on androgens and also that it decreases the androgens $(9,24)$. When androgens were monitored, DHEAS decreased in two groups slightly, total testosterone decreased in both groups significantly and no significant difference was determined between the groups.

In menopause period, fibrinogen increases with age and clearly decreases in HT areas ${ }^{(25)}$. Fibrinogen is one of the independent risk factors for myocardium infarction and paralysis ${ }^{(25)}$. In the study, fibrinogen decreased in both groups and this decrease was found statistically significant in NETA group. In literature it has been reported that NETA decreases ${ }^{(8)}$ or doesn't affect(26) whereas drospirenone doesn't affect $(11,16)$ or increases ${ }^{(27)}$ the fibrinogen. Kluft et al determined that APTT decreased with drospirenone and stated that changes in haemostatic parameters are related to the estrogen dose rather than the gestagen in combined preparations $(27)$.

HT increases TBG, total $\mathrm{T}_{3}$, total $\mathrm{T}_{4}$ levels whereas it doesn't affect TSH, free $\mathrm{T}_{3}$ and free $\mathrm{T}_{4}$ levels ${ }^{(28)}$. Therefore it is recommended to monitor TSH, free $\mathrm{T}_{3}$ and free $\mathrm{T}_{4}$ levels in order to determine the thyroid axis in women having $\mathrm{HT}^{(28)}$. In this study it was determined that NETA and drospirenone don't affect $\mathrm{TSH}$, free $\mathrm{T}_{3}$ and free $\mathrm{T}_{4}$ levels.

The first result different from the literature is the triglyceride increase in drospirenone group. Smoking ratio was determined to be significantly high in drospirenone group after the randomization; this high smoking ratio may also have caused the triglyceride increase. Because nicotine causes lipolysis with stimulation of sympathetic nervous system and decrease of catecholamine and as a result total cholesterol and triglyceride increase ${ }^{(29)}$. Besides, smoking changes the positive effects of estrogen on lipid profile by affecting the bioavailability of estrogen taken orally(18). Second difference is that drospirenone didn't cause statistically significant decrease in androgens though it has an antiandrogenic effect. Small sample size of work groups may have caused this.

Continuous combined low dose HT regimen is a good choice for the women in menopause who don't want the monthly bleedings caused by cyclic treatment. In the first months of treatment with this preparations, vaginal bleedings may be seen more frequently but they have the tendency to decrease in time ${ }^{(30,31)}$. These bleedings seen in the first 3 months may reflect endometrial compatibility ${ }^{(30)}$. Vaginal spotting was seen in $9.5 \%$ cases in NETA group and $15 \%$ cases in drospirenone group but this difference wasn't found significant. Endometrial thickness demonstrated a slight increase without significance in both groups.

Limitations of our study were small sampling size, short treatment duration and absence of a control group. Reasons for these are providing car for a limited numbers of case groups and that the subjects didn't lean towards medicine usage in menopause. Besides, patient population of low socio-economical level who immigrated from the countryside was big in our hospital so we had to limit the study period in 3 months due to both the difficulty of case follow-up and orientation to treatment, and the tendency to quit the long term treatment, medicine usage in particular.

Consequently, there are positive effects of NETA on haemostatic parameters and androgens apart from its positive effects on carbohydrate and lipid metabolism. Drospirenone affects the lipid metabolism and androgens positively except the triglyceride increase whereas it doesn't affect the carbohydrate metabolism. Low dose HT containing NETA would be a more appropriate choice especially for the cases with insulin resistance and diabetes risk in order to decrease the vasomotor symptoms. However studies with more subjects and long follow-up periods are required in order to get to a definite conclusion.

\section{REFERENCES}

1. Writing Group for the Women's Health Iniative Investigators. Risks and benefits of estrogen plus progestin in healthy postmenopausal women. JAMA 2002; 288: 321- 33.

2. Baerug U, Winge $\mathrm{T}$, Nordland $\mathrm{G}$, et al. Do combinations of $1 \mathrm{mg}$ estradiol and low doses of NETA effectively control menopausal symptoms? Climacteric 1998; 1: 219- 28.

3. Stadberg E, Mattsson LA, Uvebrant M. 17 ß-Estradiol and norethisterone acetate in low doses as continuous combined hormone replacement therapy. Maturitas 1996; 23: 31- 9 .

4. Sitruk-Ware R. Progestins in the menopause. J Steroid Biochem Mol Biol 1999; 69: 185- 93. 
5. Stadberg E, Mattsson LA, Uvebrant M. Low doses of 17 ßestradiol and norethisterone acetate as a continuous combined replacement therapy in postmenopausal women: lipid metabolic effects. Menopause 1996; 3: 90- 6 .

6. Dansuk R, Unal O, Karsidag YK, Turan C. Evaluation of the effects of various gestagens on insulin sensitivity, using homeostatic model assessment, in postmenopausal women on hormone replacement therapy. Gynecol Endocrinol 2005; 20(1): 15.

7. J.Hsu SH, Cheng WC, Jang MW, Tsai KS. Effects of long term use of raloksifene, a selective estrogen receptor modulator, on thyroid function test profiles. Clin Chem 2001; 47(10): 1865 -

8. Borgfeldt C, Li C, Samsioe G. Low dose oral combination of 17beta-estradiol and norethisterone acetate in postmenopausa women decreases factor VII, fibrinogen, antithrombin and plasminogen activator inhibitor-1. Climacteric 2004; 7(1): 7885

9. Christodoulakos G, Lambrinoudaki I, Panoulis C, Sioulas V, Rizos D, Caramalis G,Botsis D, Creatsas G. Serum androgen levels and insulin resistance in postmenopausal women: association with hormone therapy, tibolone and raloxifene. Maturitas 2005; 50(4): $321-30$

10. Christiansen C. Effects of drospirenone/ estrogen combinations on bone metabolism. Climacteric 2005; 8: 35- 41.

11. Casanova G, Radavelli S, Lhullier F, Spritzer PM. Effects of nonoral estradiol-micronized progesterone or low-dose oral estradiol-drospirenone therapy on matabolic variables and markers of endothelial fuction in early postmenopause. Ferti Steril 2009; 92(2): 605- 12. Equb 2008 Aug 15.

12. Matthews DR, Hosker JP, Rudenski AS, Naylor BA, Treacher DF, Turner RC. Homeostasis model assessment: insulin resistance and $\beta$ cell function from fasting plasma glucose and insulin concentrations in man. Diabetologia 1985; 28: 412- 19.

13. Loh FH, Chen LH, Yu SL, Jorgensen LN. The efficacy of two dosages of a continuous combined hormone replacement regimen. Maturitas 2002; 26: 41(2): 123- 31.

14. Sporrong T, Hellgren M, Samsioe G, Mattsson LA. Metabolic effects of continuous estradiol-progestin therapy in postmenopausal women. Obstet Gynecol. 1989; 73: 754- 8.

15. Warming L, Ravn P, Nielsen T, Christiansen C. Safety and efficacy of drospirenone used in a continuous combination with 17 beta-estradiol for prevention of postmenopausal osteoporosis. Climacteric. 2004; 7(1): 103- 11.

16. Archer DF, Thorneycroft IH, Foegh M, Hanes V, Glant MD, Bitterman P, Kempson RL. Long-term safety of drospirenoneestradiol for hormone therapy: a randomized, double-blind, multicenter trial. Menopause 2005; 12(6): 716- 27.
17. Sitruk-Ware R. Pharmacology of different progestogens: the special case of drospirenone. Climacteric. 2005; 8 Suppl 3: 4- 12 .

18. Tanko LB, Christiansen C. Effects of 17beta-oestradiol plus different doses of drospirenone on adipose tissue, adiponectin and atherogenic metabolites in postmenopausal women. J Intern Med 2005; 258(6): 544- 53.

19. Oelkers W, Foidart JM, Dombrovicz N, Welter A, Heithecker R. Effects of a new oral contraceptive containing an antimineralocorticoid progestogen, drospirenone, on the renin-aldosterone system, body weight, blood pressure, glucose tolerance, and lipid metabolism. J Clin Endocrinol Metab 1995; 80(6): 181621.

20. Gaspard U, Endrikat J, Desager JP, Buicu C, Gerlinger C, Heithecker R. A randomized study on the influence of oral contraceptives containing ethinylestradiol combined with drospirenone or desogestrel on lipid and lipoprotein metabolism over a period of 13 cycles. Contraception 2004; 69(4): 2718.

21. Sitruk-Ware R. Progestins and cardiovascular risk markers. Steroids 2000; 65(10- 11): 651- 8 .

22. Walker RJ, Lewis-Barned N, Sutherland WHF, Goulding A, Edwards EA, DE Jong SA, Gold E, Walker HL. The effects of sequential combined oral $17 \AA$ estradiol norethisterone acetate on insulin sensitivity and body composition in healthy postmenopausal women: a randomised single blind placebo controlled studt. Menopause 2001; 8: 27- 32 .

23. Spencer CP, Goldsland IF, Cooper AJ, Ross D, Whitehead MI, Stevenson JC. Effects of oral and transdermal 17 ß estradiol with cyclical oral norethindrone acetate on insulin sensitivity, secretion and elimination in postmenopausal women. Metabolism 2000; 49: 742- 7 .

24-. Sitruk-Ware R. Progestins in the menopause. J Steroid Biochem Mol Biol 1999; 69(1- 6): 185- 93.

25. Yilmazer M, Fenkci V, Fenkci S, Sonmezer M, Aktepe O, Altindis M, Kurtay G. Hormone replacement therapy, Creactive protein, and fibrinogen in healthy postmenopausal women. Maturitas 2003; 10: 46(4): 245- 53.

26. Hofling M, Carlstrom K, Svane G, Azavedo E, Kloosterboer H, Von Schoultz B. Different effects of tibolone and continuous combined estrogen plus progestogen hormone therapy on sex hormone binding globulin and free testosterone level an association with mammographic density. Gynecol Endocrinol 2005; 20(2): 110- 5 .

27. Kluft C, Endrikat J, Mulder SM, Gerlinger C, Heithecker R. A prospective study on the effects on hemostasis of two oral contraceptives containing drospirenone in combination with either 30 or 20 mug ethinyl estradiol and a reference containing 
desogestrel and 30 mug ethinyl estradiol. Contraception 2006; 73(4): 336- 43

28. Benencia H, Ropelato MG, Rosales M, Mesch V, Siseles N, Boero L, Fogel M, Donato AM, Petroff N, Dourisboure R. Thyroid profilemodifications during oral hormone replacement therapy in postmenopausal women. Gynecol Endocrinol 1998 Jun; 12(3): 179- 84.

29. Wu DW, Pai L, Sung PK, Hsu LL, Sun CA. Joint effects of alcohol consumption and cigarette smoking on atherogenic lipid and lipoprotein profiles: Results from a study of Chinese male population in Taiwan. Eur J Epidemiol 2001; 17: 629- 35.
30. Hillard TC, Siddle NC, Whitehead MI, Fraser DI, PryseDavies J. Continuous combined conjugated equine estrogenprogestogen therapy: effects of medroxyprogesterone acetate and norethindrone acetate on bleeding patterns and endometrial histologic diagnosis. Am J Obstet Gynecol 1992; 167(1): 17.

31. Schurmann R, Holler T, Benda N. Estradiol and drospirenone for climacteric symptoms in postmenopausal women: a doubleblind, randomized, placebo-controlled study of the safety and efficacy of three dose regimens. Climacteric 2004; 7(2): 18996. 